\title{
A Látrányi Puszta Természetvédelmi Terület általános környezeti jellemzése és kutatása
}

A Látrányi Puszta Természetvédelmi Terület a Dunántúli-dombságon, Külső-Somogy középtájon, azon belül Nyugat-Külső-Somogy kistájon fekszik (1. ábra). A 8/1992. (III.25) KTM rendelet nyilvánította országos jelentőségủ természetvédelmi területté. A védett terület jelenleg nemzetközi egyezmény hatálya alá nem esik. Területe: 223,5868 ha, tszf magassága: 116,8 m - 143,1 m között ingadozik.

A terület a Duna-Dráva Nemzeti Park Igazgatóságához tartozik, a védett területen a tájegységvezető: Rozner György.

A védett terület főként gyep művelési ágba tartozik (1. táblázat).

1. táblázat: A védett terület múvelési ágak szerinti megoszlása

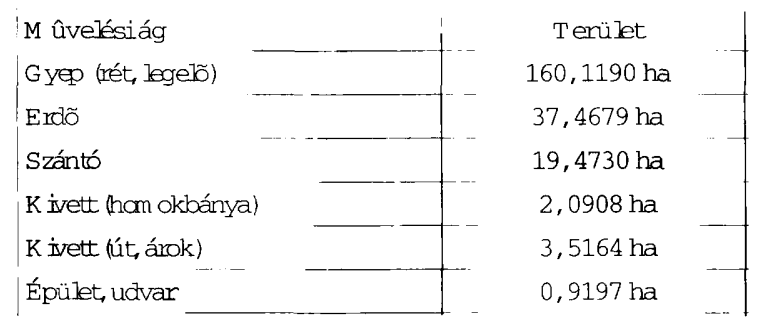

A terület tájtörténete

A terület tájtörténetéről csak szórványos adatokat ismerünk. A 14. században királyi birtok volt, attól kezdve a 20. századig különböző főúri családok birtoka. A II. József korabeli katonai felmérés (1782-85) térképszelvényén jól láthatóan a maihoz hasonló puszta, amelynek csak a DK-i részein vannak fás ligetek (2. ábra). Az azóta eltelt időben a területet csak részben hasznosították legelöként.

\section{Környezeti jellemzők}

\section{Földtan}

A terület földtani alapját harmadidőszaki üledékek alkotják, ezek a felszínre homok formájában bukkannak a természetvédelmi területtől nyugatra fekvő Birkás-legelőn, ugyanakkor a felszínt negyedidőszaki üledékek fedik. A természetvédelmi terület alacsonyabban fekvő része valaha a Balaton öblözete volt; itt tavi homok halmozódott fel, amit az északi, bakonyi szél áthalmozott, homokbuckákat épített a terület magasabb nyugati részén. Az alacsonyabb keleti részén a Tetves-patak üledékei fedik a közvetlen felszínt. 


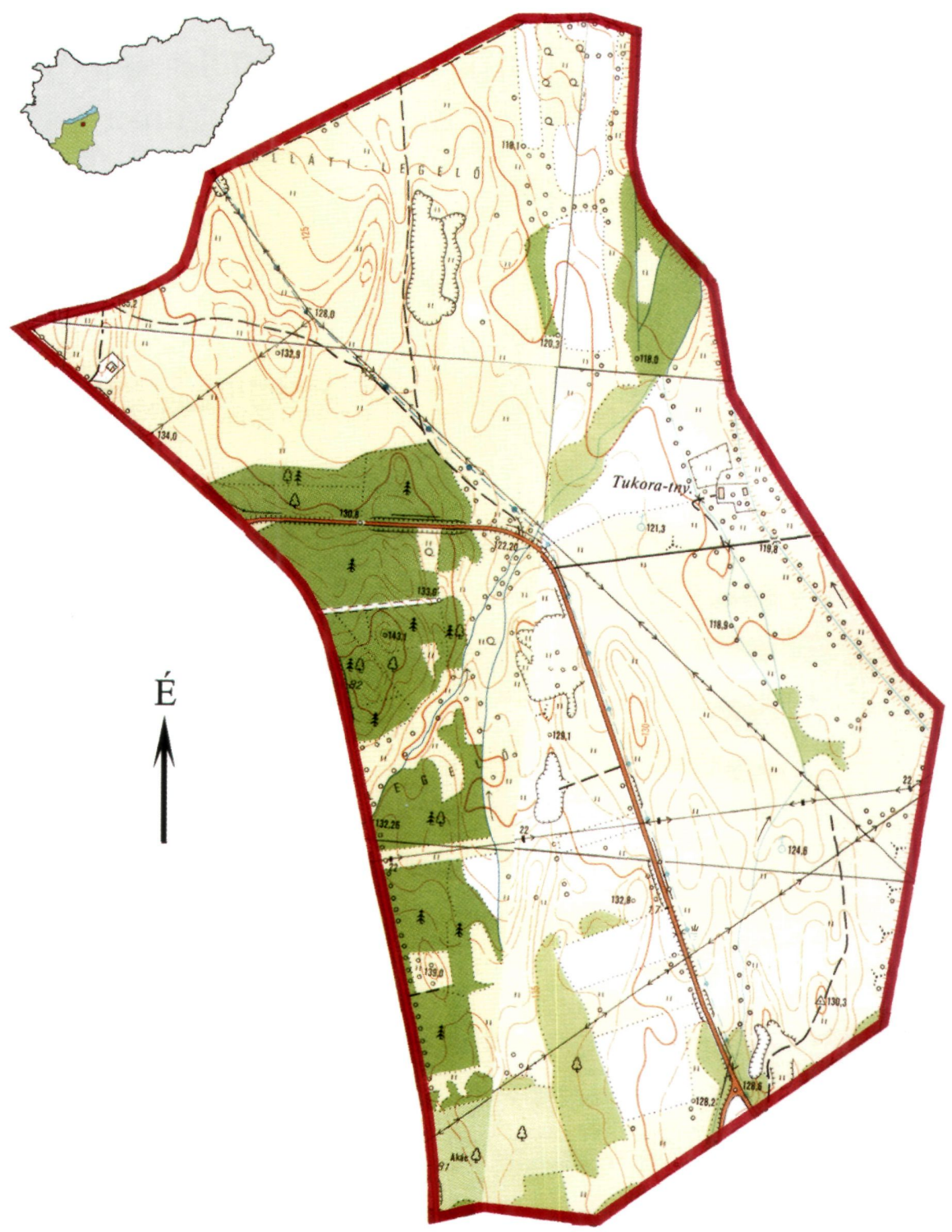

1. ábra: A Látrányi Puszta Természetvédelmi Terület határai 


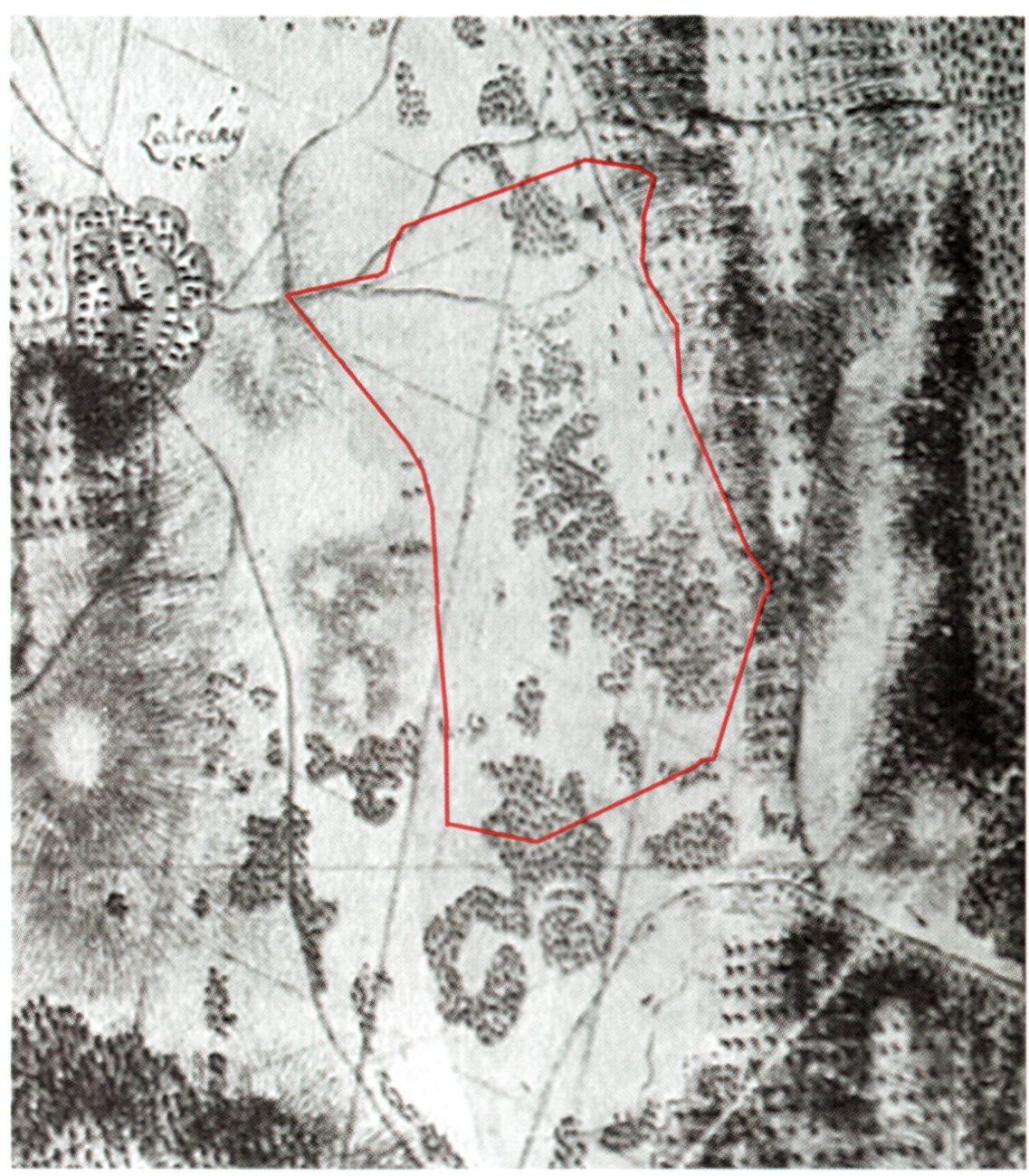

2. ábra: A II. József korabeli katonai felmérés (1782-85) térképe és a jelenlegi védett terület hozzávetőleges elhelyezkedése

\section{Felszinalaktan}

A védett terület $130 \mathrm{~m}$ átlagos tszf. magasságban helyezkedik el. Legmagasabb része a természetvédelmi terület DNY-i részén található homokdombtetőn $(143,1 \mathrm{~m})$, legalacsonyabb része ÉK-en $(116,8 \mathrm{~m})$ van.

A sík felszínen a domborzat mozgalmasságát a területen kiemelkedő homokbuckák növelik, relatív magasságuk $10 \mathrm{~m}$.

A felszín relief energiáját növelik a buckák közötti mélyedések, hosszanti szélbarázdák és az időszaki vízfolyások széles, lapos völgyei valamint a homokbányászat által okozott tájsebek.

\section{Éghajlat}

A védett terület éghajlata mérsékelten meleg - mérsékelten nedves. Napsütéses órák száma: 2000 óra, évi középhőmérséklete: $10,2{ }^{\circ} \mathrm{C}$, a vegetációs időszaké $16,8-17,2{ }^{\circ} \mathrm{C}$. A fagymentes időszakok hossza 205 nap (ápr. 5. - okt. 28. között). 


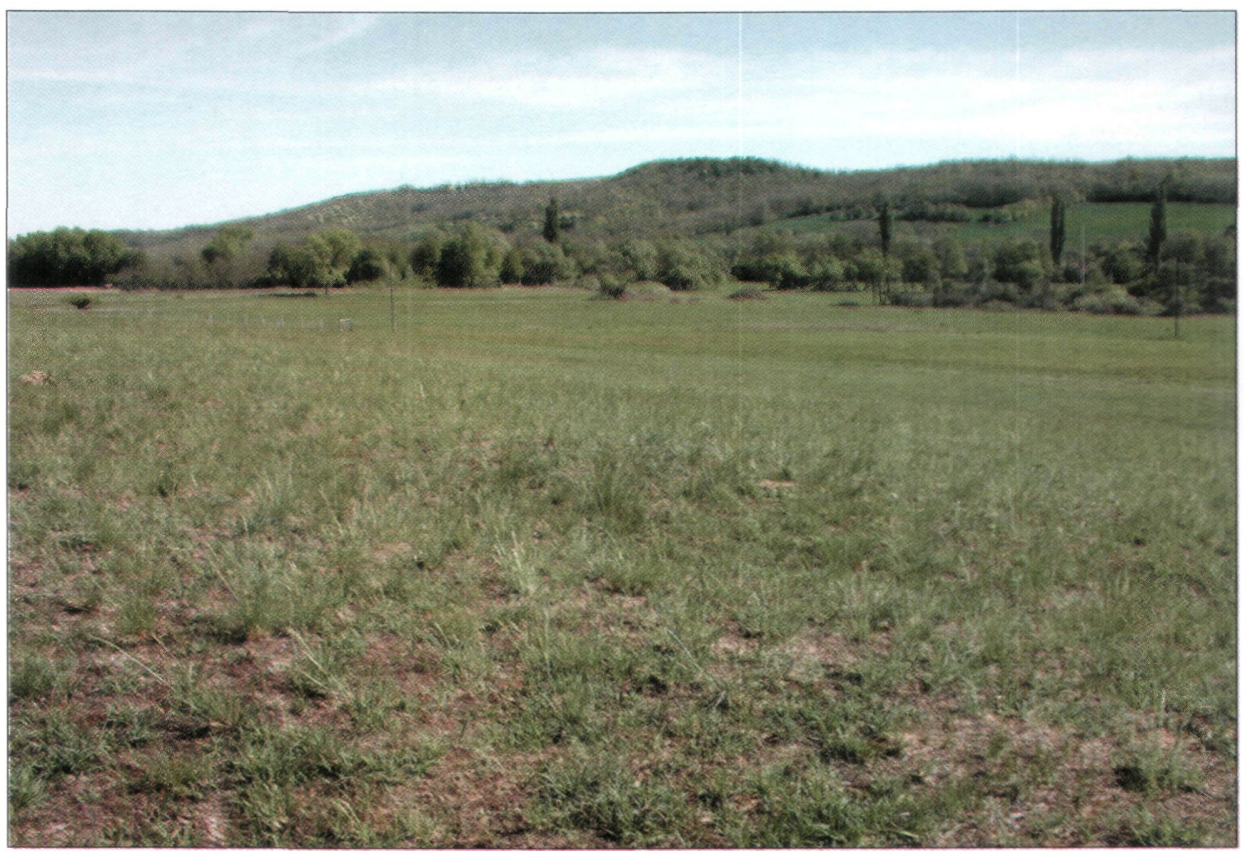

3. ábra: Látkép a puszta délkeleti részén

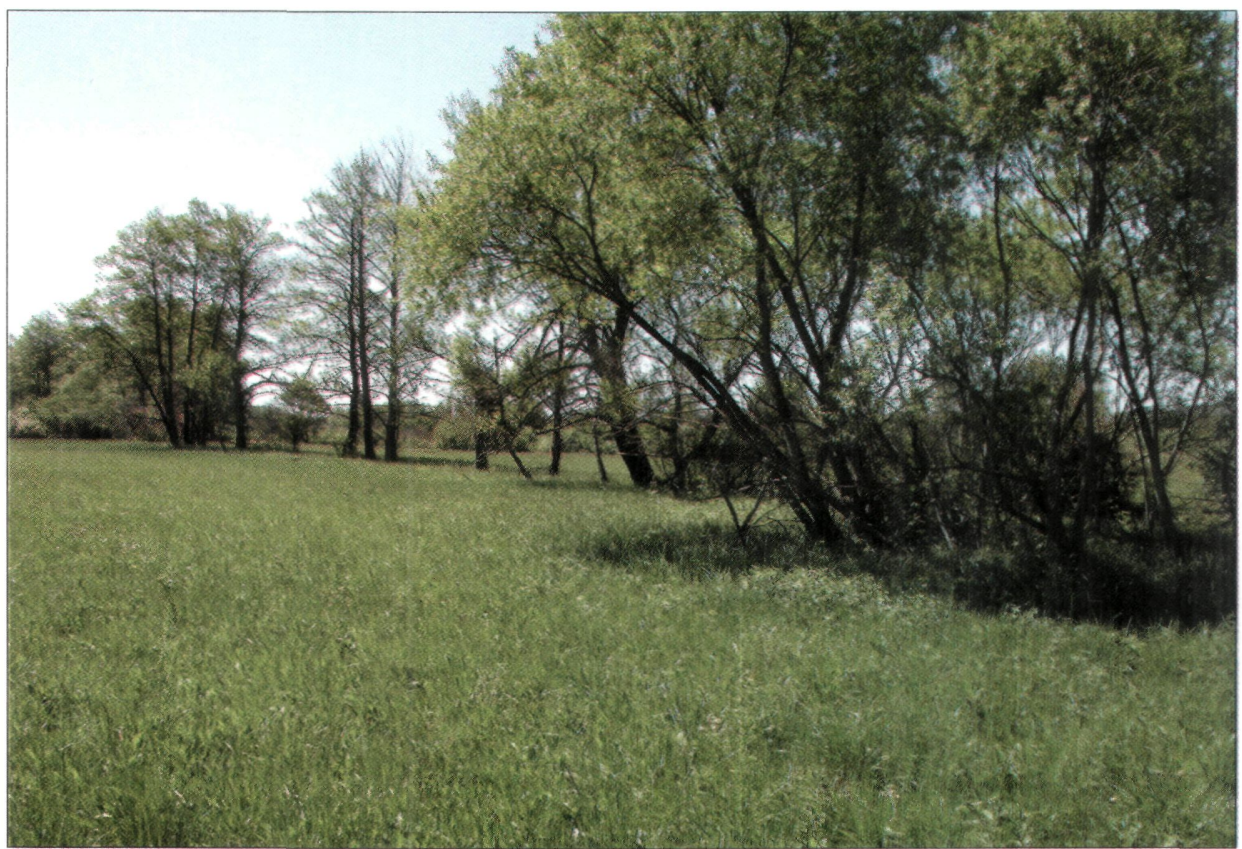

4. ábra: A Malomárok környéki fás ligetek és nedves rétek 
Legmagasabb nyári hömérsékletének sokévi átlaga: $33,5^{\circ} \mathrm{C}$, a téli minimumoké $-15^{\circ} \mathrm{C}$. Évi csapadékösszeg: $650 \mathrm{~mm}$, amiböl a vegetációs időszakban $400-420 \mathrm{~mm}$ eső esik. A hótakarós napok száma 35-38 nap/év. Az ariditási index: 1,08.

Leggyakoribb szélirányok: Ny-i és É-i, átlagos sebessége: $3 \mathrm{~m} / \mathrm{s}$.

A helyi sajátosságok között ki kell emelni a láprétek feletti magas páratartalmat és a gyakori éjszakai ködképződést.

A terület homok alapkőzete fizikai tulajdonságainál fogva szintén sajátos mikroklimával rendelkezik. A csapadékvizet gyorsan átengedi, ezért könnyen kiszárad. A nyílt homokfoltok talajfelşzíni hőmérséklete elérheti az 55-60 ${ }^{\circ} \mathrm{C}$-ot nyári derült napokon.

\section{Vizrajz}

A vízföldtani viszonyok jelenleg még feltáratlanok. A talajvíz átlagos mélysége a völgyekben 2-4 m. Ezt mutatja a terület DK-i részén lévő gémeskút is. A talajvíz kalciummagnézium-hidrokarbonátos jellegü, 25-35 nk keménységü. A nitrátosodás kiterjedt. A talajvíz mozgása ÉK-i irányú.

A védett terület hidrológiai központja a Tetves-patak. A Vadé-puszta melletti völgyi vízválasztója mintegy $25 \mathrm{~km}$ távolságra van a Balatontól. Vízgyüjtő területének nagysága mintegy $94 \mathrm{~km}^{2}$, közepes vízhozama $0,2 \mathrm{~m}^{3} / \mathrm{s}$. A Tetves-patak a természetvédelmi terület keleti határa mentén csatornázott, rajta több helyen hordalék ülepítők találhatók. A felszíni vizek ezen a patakon keresztül jutnak a Balatonba.

A természetvédelmi területen 4 efemer vízfolyás található, ezek a nyári időszakban kiszáradnak. Nevük nincs. Jelentöségük a láprétek vízutánpótlásában viszont rendkívül nagy.

Időszaki kisebb állóvizek a felhagyott homokbánya gödrökben találhatók a tavaszi és a nyár eleji időszakban. Nedves években fontos kétéltü szaporodási helyek.

\section{Talajok}

A természetvédelmi terület kb. 70\%-át karbonátos homoktalaj fedi. A váztalaj jellemzője, hogy az egyes talajszintek még nem fejlődtek ki. A humuszképződés gyenge, gyér növényzet borítja. A vizet gyorsan elnyeli. Könnyen kiszárad, ennek következtében a szerves anyagok gyorsan ásványosodnak.

Humuszos homoktalajok a terület 10\%-án találhatók. Ezekben a humuszszint morfológiailag fejlettebb, a humusztartalom 1\%-nál nagyobb. Víztartó képességük is jobb, mint az elöző talajtípusé, ugyanakkor vízáteresztő képességük is jó. A sekély humuszréteg vastagsága $10-30 \mathrm{~cm}$. A védett területen belül ezek elsősorban a jelenlegi erdők és szántók alatt találhatók.

$\mathrm{Az}$ efemer vizek mentén és néhol a mélyebben fekvő buckaközökben rétláp talajok fordulnak elö. Ezeket az év első részében magas vízállás jellemzi. Néhol a gyenge kotusodás is megfigyelhető. Vízgazdálkodásuk és tápanyag gazdálkodásuk szélsőséges. Szervesanyag tartalmuk elérheti a $10 \%$-ot, $\mathrm{pH}$-juk gyengén savanyú is lehet.

A természetvédelmi terület megközelítőleg sík felszínü részén a talajerózió nem jellemző, de a Tetves-patak menti területek a külső-somogyi talajerózió akkumulációs területének tekinthetök. 


\section{Természetvédelmi kutatás}

- A látrányi puszta a terület védetté nyilvánítása elött az Egri Tanárképző Főiskola terepgyakorlati mintaterülete volt, ezért innen már ekkor megbízható botanikai és zoológiai információkat ismertünk.

- A Balaton déli partvidéke patakjainak vizsgálata során, a természetvédelmi terület szegélyén futó Tetves-patakon hidrozoológiai felmérést végzett az MTA Balatoni Limnológiai Kutató Intézete OTKA pályázat támogatásával. Témavezető: Dr. Ponyi Jenő.

- A védetté nyilvánítás után a "Somogy természeti értékeinek feltárása" címủ OTKA pályázat keretében a Somogy Megyei Múzeum Természettudományi Osztálya vizsgálta a terület botanikai és zoológiai értékeit 1990-1994 között. Témavezető: Dr. Ábrahám Levente.

- Ezt követően 1999-ben a terület természetvédelmi alapfauna feltárása érdekében a Duna-Dráva Nemzeti Park anyagi támogatásával vizsgáltuk (Rozner György, Józan Zsolt és Ábrahám Levente)a terület Coleoptera (bizonyos családok), Neuroptera, Hymenoptera: Aculeata és Lepidoptera faunáját.

- 2001-ben egy sikeresen elnyert KAC pályázat (Témavezető: Dr. Ábrahám Levente) keretében került sor a terület legfontosabb csoportjainak természetvédelmi felmérésére.

- Ezenkívül számos kutató egyéni kutatói pályázata keretében vett részt a terület alapfaunájának feltárásában.

Jelen tanulmánykötet a védett területen történt kutatások összefoglalója.

\section{Irodalom}

ÁBRAHÁM L. (szerk.) 1990-1994: Somogy természeti ćrtékeinck kutatása (OTKA kutatási jelentés nysz: 2335) SMMI Term.Tud. Oszt., Kaposvár Adattár, kézirat

ÁBRAHÁM L. (szerk) 1999: A Látrányi Puszta Természetvédelmi Terület természetvédelmi, zoológiai felmérésc (kutatási jelentés) - SMMI Term.Tud. Oszt., Kaposvár Adattár, kézirat

ÁBrAHÁM L. (szerk.) 2002: Beszámoló a Látrányi Puszta Természetvédelmi Terület zoológiai alapállapotfelmérése a különbözö módon kezelt területeken (KAC kutatási jelentćs, asz.: 027866-01/2001) - SMMI Term.Tud. Oszt., Kaposvár Adattár, kézirat

ÁdÁM L., MARosı S., SzILÁRD J. 1981: A Dunántúli dombság. (Dćl-Dunántúl). - Magyarország tájföldrajza 4. Akad. Kiadó, Budapest

MARosı S. (szerk.) 1990: Magyarország kistájainak katasztere II. - MTA Földrajztudományi Kutató Intézet Budapest pp. 483-589.

Összeállította:

Dr. ÁBRAHÁm LEVENTE

Somogy Megyei Múzeum

Természettudományi Osztálya

H-7400 Kaposvár Fö u. 10.

Hungary

e-mail: levi@smmi.hu 